\title{
Eltéró órölhetóségú anyagok
}

együttórlésének alapvizsgálata

\section{univerzális Hardgrove malomban}

\author{
GREGUS ÉvA " Miskolci Egyetem - ejtgrege@uni-miskolc.hu \\ RÁCZ ÁDÁM - Miskolci Egyetem • ejtracz@uni-miskolc.hu \\ CSŐKE BARNABÁs - Miskolci Egyetem - ejtcsoba@uni-miskolc.hu \\ Érkezett: 2018. 01. 17. - Received: 17. 01. 2018. " https://doi.org/10.14382/epitoanyag-jsbcm.2018.17
}

\section{Intergrinding of materials with different grindability in Universal Hardgrove mill}

The most energy and price consuming process in a mineral processing technology is grinding. In this study materials with different grindability were prepared and used for separate and intergrinding experiments. Quartz and limestone were used for the two components intergrinding, where the quartz is hard to grind and non-adhesive, but the limestone is easy to grind and adhesive. The grinding experiments were carried out in a Universal Hardgrove Mill. The ground material was examined in laser particle size distribution analyser and optical microscope to determine the particle size distribution and investigate the particle shape as well. During the grinding experiments grinding work was measured based on torque measurement. In case of intergrinding the material composition in different size fractions were determined by loss on ignition measurement. The Bond work index of the materials were calculated from the torque measurement results. Based on the measurement results the different grinding behaviour of the quartz and limestone can be seen. The limestone was fractured easily at the beginning of grinding, while at longer grinding times sticking and agglomeration of the particles occurred, while the efficiency of the grinding was significantly decreased. Contrary, quartz was fractured slightly in the grinding chamber, only attrition of the particles surface occurs and not body breakage. This can be traced back to the spherical shape of the quartz particles. Based on the results of the intergrinding it can be conclude that the increasing limestone content in the feed resulted in ground material with lower particle size and higher specific surface at a constant specific grinding work. The material composition of the ground materials in different size fractions showed that the limestone was enriched in the fine $(<20 \mu \mathrm{m})$ fraction at the intergrinding. The quartz particles participate in the grinding like a grinding media. From the intergrinding of different size fractions of one material it can be conclude that the grinding of quartz resulted in high amount of fine, less than $1 \mu \mathrm{m}$ product. So, in this case as well mainly the attrition of the quartz particles was carried out.

Keywords: Two components intergrinding, Universal Hardgrove mill Kulcsszavak: Kétkomponensú együttôrlés, Universal Hardgrove malom
GREGUS Éva

2017-ben szerezett Bsc diplomát a Miskold Egyetem Müszaki Földtudományi Karán, mũszaki földtudományi alapszakon nyersanyagelökészitési specializáción. Jelenleg tanszéki mérnökként dolgozik az Miskolc Egyetem, Nyersanyagelökészitési és Környezet Eljárástechnikai Intézetében a „Fenntartható Nyersanyag-gazdálkodási Tematikus Hálózat RING 2017" címü, EFOP-3.6.2-16-2017-00010 jelü projekt keretében.

RÁCZ Ádám

2008-ban végzett a Miskolci Egyetem, Mứszaki Földtudományi Karán, elốkészitéstechnikai mérnök szakon. Doktori (PhD) fokozatát 2014 ben szerezte ôrlés tématerületén. Jelenleg a Miskolci Egyetem, Nyersanyagelőkészités és Környezeti Eljárástechnikai Intézetének adjunktusa. Fổ kutatási és oktatási területe a mechanikai eljárástechnika és az apritás, ôrlés.

csōKE Barnabás

A Miskolci Egyetem, Mứszaki Földtudomány Karának Professzor Emeritusza. Okleveles bányamérnökként végzett 1969-ben a Miskolci Egyetem, Bányamérnöki Karán. Mû́szaki tudomány kandidátusa címet 1976-ban, PhD fokozatát 1986-ban szerezte. 1997-ben Habilitációs fokozatot szerzett 1998-2016 között egyetemi tanár a Miskolci Egyetemen. Fổ kutatási és oktatási területe a mechanikai eljárástechnika, aprítás, ôrlés, hulladékelőkészités.

\section{Bevezetés}

Az egyik legnagyobb energiaigényű nyersanyag-előkészítési folyamat az aprítás, őrlés [1,2] és ennek köszönhetően jelentős költséghányadot képvisel egy ásványelőkészítési technológia üzemeltetésében. Annak érdekében, hogy az energiafelhasználást minimalizálni tudjuk az üzemi és gépi pataméterek optimálása az őrlendő anyagok tulajdonságainak ismeretében kiemelt fontosságú feladat. Az eltérö örölhetőségü anyagok együttőrlésére számos alkalmazást találunk az iparban, kiemelt példája a cementiparban a klinker egyéb hidraulikus kötőanyagokkal és töltőanyagokkal keverékként való őrlése. A folyamatok megértéséhez ki kell emelni, hogy az együttőrlés során a különböző őrölhetőségü szemcsék hatással vannak egymásra, a nagyobb méretü és nehezebben őrölhető anyag szemcséi kvázi örlőtestként müködhetnek vagy a finomabb anyag bevonatot képezhet a nagyméretű és nehezebben őrölhető szemcsék felületén. Csőke és társai [3] különböző őrölhetőségű anyagok Bond és Hardrove malomban való együttőrlésével foglalkoztak, a különböző módon meghatározott Bond-indexek eltérését vizsgálták. Méréseiket összekapcsolták az alkotórészek tö- megarányának meghatározásával az őrleményben, az őrléseket nem az örölhetőségi koefficiens állandósult állapotáig hajtották végre, hanem az alkotórészek összetételbeli kémiai egyensúlyáig folytatták le. Ipek [4] szerint a lágyabb komponenst tartalmazó keverékek Bond munkaindexei nagyobbak, mint az egyedi alkotók munkaindexeinek súlyozott átlaga a keverékekben. Öner [5] a Bond mérést klinker és kohósalak keverékén végezte el. Megmutatta, hogy a keverékek Bond őrölhetősége alacsonyabb, mint az összetevők őrlésének súlyozott átlaga az összes salak hozzáadása esetén. Együttőrlésnél az alacsonyabb örölhetőségű salak a durvább frakcióban halmozódik fel, míg a klinker a nagyobb örölhetőség miatt a finomabb frakcióban dúsul. Abouzeid és Fuerstenau [6] a nagy nyomású őrlőhengereket (HPGR) vizsgálták. Rávilágítottak, hogy a nagy keménységű ásványi részecskék energiatranszferként müködnek a hengerek réseiben és fokozzák a puhább ásványi részecskék őrlését a kevert feladásban. Tavares [7] szerint a durvább szemcsék által a HPGR-ben tapasztalt nagyobb gyengülés csökkenti az energia-megtakarítást és a termék további őrlésének finomabb méretét. Ellerbrock és munkatársainak [8] eredményei alapján a cementkomponensek részecskeméret-eloszlása függ az őrlö- 
rendszer típusától és müködési módjától, valamint a cementkomponensek őrölhetőségétől. Faitli és munkatársai [9] üzemi vizsgálatokat hajtottak végre az őrlési energiaigény optimalizálása érdekében egy vertikális görgős malomban, melyhez léces szélosztályozó kapcsolódik. Kifejlesztésre került egy finomítási és három szétválasztási szakasz a minőségi termék előállítása céljából. Több mintavételi pont és modellezés segítségével állapították meg az optimalizáláshoz szükséges anyagáramokat és a légszeparátor fordulatszámát. Az üzemi adatokból Bond munkaindex került számításra. A fentiekkel összefüggésben a kutatómunka célja a kétkomponensü rendszerek együttőrlésének vizsgálata univerzális Hardgrove malomban és az őrlés során lejátszódó szemcse kölcsönhatásoknak a vizsgálata.

\section{Anyagok és eljárások}

A méréseket és vizsgálatokat a Nyersanyagelőkészítési és Környezeti Eljárástechnikai Intézet laboratóriumaiban és eszközein végeztük el. A kétkomponensű őrlési kísérletekhez kvarcot és mészkövet használtunk. Első lépésként előállítottuk a méréshez megfelelő kiindulási alapanyagokat. Laboratóriumi szitákat használva 106-250 $\mu \mathrm{m}$ és 32-106 $\mu \mathrm{m}$ közötti frakciókat hoztunk létre nedves szitálással, majd szárítószekrényben $105{ }^{\circ} \mathrm{C}$-on kiszárítottuk a frakciókat. Az őrlési kísérletekhez univerzális Hardgrove malmot alkalmaztunk. Univerzalitása abban található, hogy nem csak az őrlési körülmények, hanem a hőmérséklete is változtatható $20-300{ }^{\circ} \mathrm{C}$ között, illetve képes az őrléshez szükséges munka direkt mérésére nyomatékmérés segítségével. A berendezés fejlesztés egyik célja az volt, hogy az üzemi viszonyokat jobban megközelítő, magasabb hőmérsékleteken is el lehessen végezni az őrölhetőségi vizsgálatokat. Ezért a malmot (az őrlőtégelyt) a fütését szolgáló tégelykemencével vették körül $[2,11]$. Az őrlések során a szabványos Hardgrove őrlés körülményeit alkalmaztuk ( $8 \mathrm{db}$ őrlőgolyó, $\mathrm{F}=$ 290 N, fordulatszám 20 1/perc). Minden őrlési kísérlet során az univerzális Hardgrove malomra $\mathrm{V}_{\mathrm{H}}=58 \mathrm{~cm}^{3}$-nek megfelelö tömegü anyag került feladásra [10].

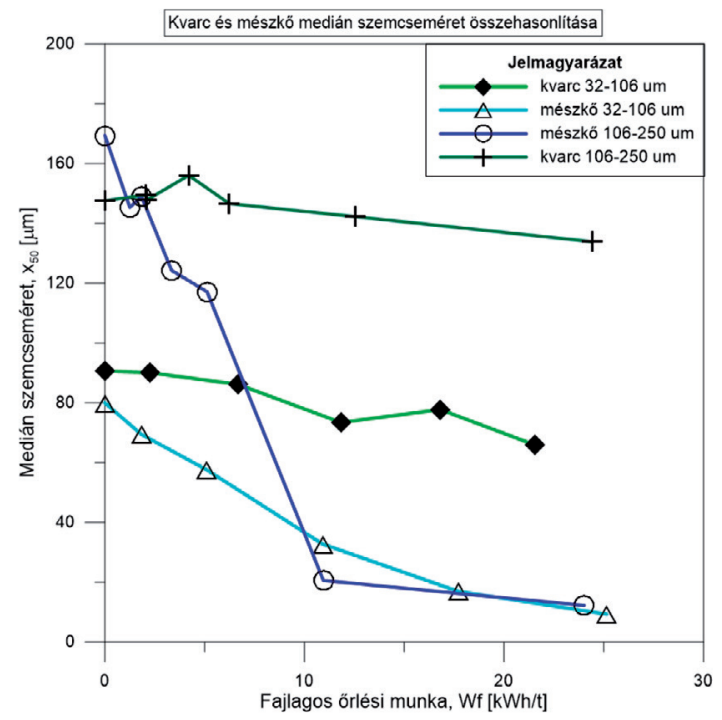

1. ábra Mészkő és kvarc mediánjának változása a fajlagos őrlési munka függvényében különőrlés esetén

Fig. 1 Median particle size of limestone and quartz as a function of the specific grinding work in case of separate grinding
A fajlagos örlési munka $\left(W_{f}\right)$ értékek a nyomatékmérésen alapuló mérési eredményekből $\left(\mathrm{W}_{\mathrm{f} \text {,mért }}\right)$ kerültek meghatározásra minden őrlési kísérlet során. A kiindulási anyagok és az őrlemények empirikus szemcseméret eloszlását és a számított fajlagos felületet Horiba LA-950 típusú lézeres szemcseméret elemző segítségével határoztuk meg. A különőrlési vizsgálatok során a kvarcot és mészkövet 3, 5, 10, 15, 30, 60 percig öröltük. A kétkomponensű együttőrlési vizsgálatok során különböző arányú $(25-75,50-50,75-25)$ feladásokat állítottunk elő, majd különböző ideig ( $t=5,30,60 \mathrm{~min})$ őröltük őket az univerzális Hardgrove malomban. Ezen felül végeztünk még kísérleteket arra irányulóan is, hogy hogyan viselkedik a mészkő és a kvarc együtt- és különőrlés során, ha saját anyagából kisebb szemcseméretü frakcióval őröljük együtt. Esetünkben mind a kvarc, mind a mészkő 106-250 $\mu$ m-es frakciójához 32-106 $\mu \mathrm{m}$-es anyagot kevertünk és együttörlésnél szintén 5, 30 és 60 percig, különőrlésnél $5,15,30,45$ és 60 percig végeztünk rajtuk őrlést 25-75, 50-50, 75-25 arányban keverve a frakciókat. Az együttőrlési kísérletek után az egyes őrleményeken izzítási veszteség mérést is végeztünk. Ehhez az anyagot elöször frakcionáltuk: $250>x>106 \mu \mathrm{m}, \mathrm{x}>63 \mu \mathrm{m}, \mathrm{x}>20 \mu \mathrm{m}$ és $0<\mathrm{x}<20 \mu \mathrm{m}$. Az izzítási veszteség vizsgálatánál analitikai mérleggel mértük a porcelán csónakok tömegét, bemértünk $1 \mathrm{~g}$ anyagot, majd szobahőmérsékletü kemencébe helyeztük a mintákat. A kemence 1,5 óra alatt érte el a $950{ }^{\circ} \mathrm{C}$ hőmérsékletet, majd további 1 órát volt még benn az anyag. Kihülés után mértük a tömegeket és meghatároztuk az izzítási veszteségeket.

\section{Mérési eredmények}

\subsection{Különőrlési eredmények}

A vizsgálatok során elvégeztük a mészkő és kvarc szemcsék külön őrlését, majd eltérő összetételek mellet vizsgáltuk az őrlemények diszperzitás jellemzőinek változását és az anyagok őrlés közben egymásra gyakorolt hatását. Az 1. ábrán a kvarc és mészkő két különböző frakciójának különőrlési eredménye ta-

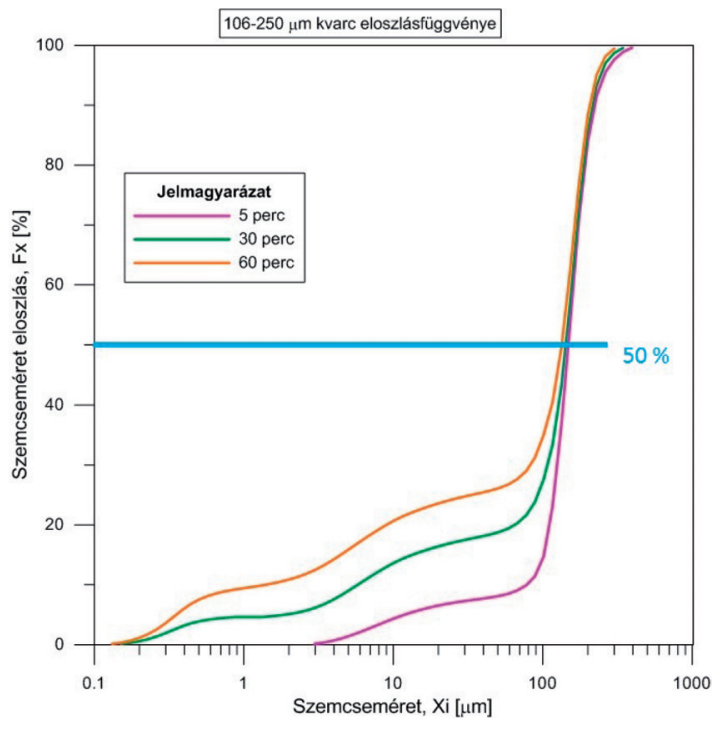

2. ábra Kvarc szemcseméretének eloszlásfüggvénye különörlés esetén Fig. 2 Cummulative undersize of quartz in case of separate grinding 


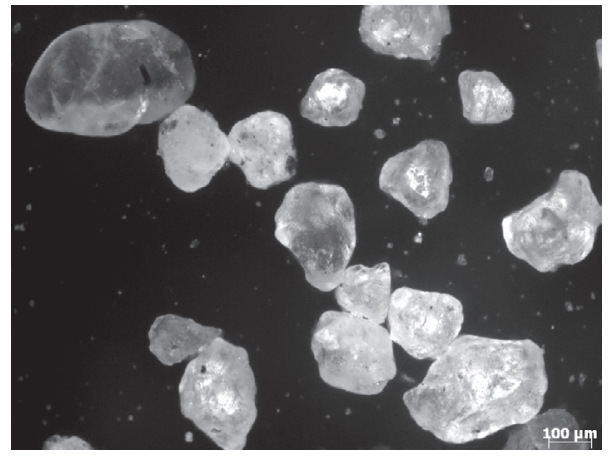

a)

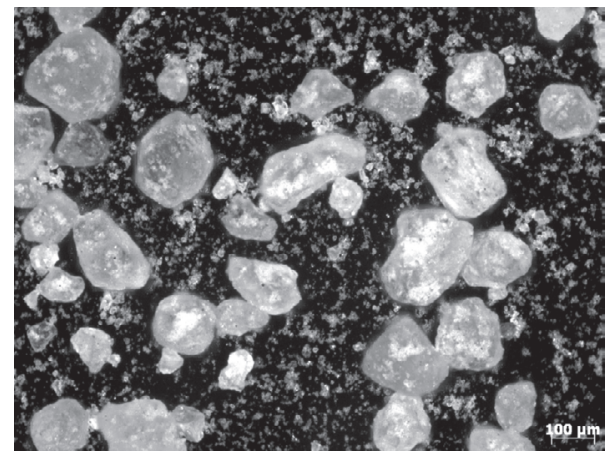

b)

3. ábra Kvarc szemcsék mikroszkópi felvételei ( $a$, kiindulási; b, 60perc) Fig. 3 Microscopic picture of quartz particles, $a$-feed, $b-60$ min grinding

lálható, ahol a medián változása látható a fajlagos őrlési munka függvényében. A kvarc kiindulási medián szemcsemérete 106$250 \mu \mathrm{m}$-es frakciónál 147,6 $\mu \mathrm{m}$-röl 133,9 $\mu \mathrm{m}$-re csökkent 25 $\mathrm{kWh} / \mathrm{t}$ fajlagos őrlési munka befektetése után. Mészkő esetén az anyag jelentős szemcseméret csökkenésen esett át, a kiindulási medián szemcseméret 169,4 $\mu \mathrm{m}$-röl 12,23 $\mu \mathrm{m}$-re csökkent $24 \mathrm{kWh} / \mathrm{t}$ fajlagos őrlési munka hatására. A kisebb, 32-106 $\mu \mathrm{m}$ es kvarc frakció csak kismértékű szemcseméret változás következett be, $91 \mu \mathrm{m}$-ről $66 \mu \mathrm{m}$-re mérséklődik a szemcsemért $21 \mathrm{kWh} / \mathrm{t}$ fajlagos őrlési munka következtében, a mészkőnél a nagyobb frakcióhoz hasonlóan jelentős a változás, $80 \mu \mathrm{m}$-ről 9,3 $\mu \mathrm{m}$-re csökkent a medián szemcseméret $25 \mathrm{kWh} / \mathrm{t}$ fajlagos őrlési munka után. A kvarc esetén a medián szemcseméret változása és a fajlagos örlési munka között lineáris összefüggést figyelhetünk meg. Ezzel ellentétben a mészkő 106-250 $\mu$ m-es frakció esetében $11 \mathrm{kWh} / \mathrm{t}$ munka és $13 \mu \mathrm{m}$ eléréséig lineárisan csökken a szemcseméret, míg ezután $24 \mathrm{~kW} / \mathrm{t}$ fajlagos őrlési munka esetén sem csökken jelentősen tovább a szemcseméret. A finomabb mészkő frakció esetében a szemcseméret csökkenése lineáris a fajlagos őrlési munkával. A kvarc-szemcsék a befektetett őrlési munka és a közölt - a Hardgrove malomban kialakuló - igénybevételek hatására nem, vagy csak alig törtek, a medián szemcseméret kismértékü csökkenése figyelhető meg a befektetett fajlagos őrlési munka függvényében. Megvizsgálva a kvarc 106-250 $\mu$ m-es frakciójának szemcseméret-eloszlás változását az őrlési idő függvényében (2. ábra), azt láthatjuk, hogy habár a medián szemcseméret alig változott, a finomabb $(<50 \mu \mathrm{m})$ szemcseméret tartományban az anyag jelentősen finomodott, a $<50 \mu \mathrm{m}$-es rész tömeghányada jelentősen megnőtt 7 \%-ról 28 \%-ra. Az $1 \mu$ m alatti szemcsék mennyisége a kvarcőrleményben szintén jelentősen növekedett $~ 1 \%$-ról
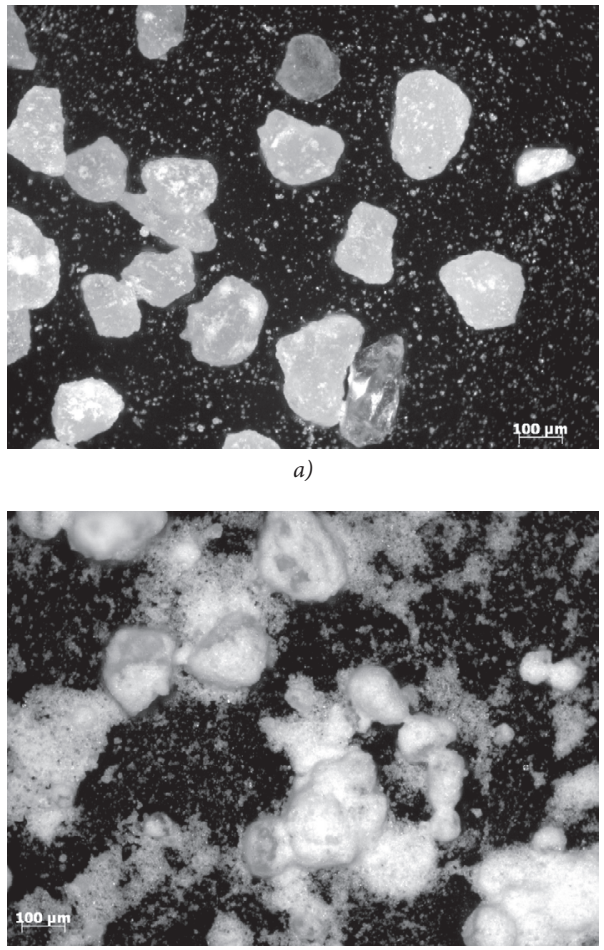

b)

4. ábra Mészkő szemcsék mikroszkópi felvételei ( $a$, kiindulási; b, 60perc)

Fig. 4 Microscopic picture of limestone particles, a-feed, $b-60$ min grinding

10-13\%-ra (2. ábra). Mindeközben a fajlagos felület is erőteljesen növekedett, kvarc esetén $326 \mathrm{~cm}^{2} / g$-ról $8054 \mathrm{~cm}^{2} / \mathrm{g}$-ra a 106-250 $\mu \mathrm{m}$-es frakciónál és $1085 \mathrm{~cm}^{2} / \mathrm{g}$-ról $8971 \mathrm{~cm}^{2} / \mathrm{g}$-ra a 32-106 $\mu \mathrm{m}$-es frakció esetében. Mészkő vizsgálatánál a 106$250 \mu$ m-es frakciónál $907 \mathrm{~cm}^{2} / g$-ról $2673 \mathrm{~cm}^{2} / \mathrm{g}$-ra, a 32-106 $\mu$ m-es frakciónál pedig $1242 \mathrm{~cm}^{2} /$ g-ról $11297 \mathrm{~cm}^{2} / g$-ra növekedett. Ennek magyarázatára azt mondhatjuk, hogy a fellépő dörzsölő igénybevétel csak koptatta a szemcsék felületét, miközben a kvarcszemcsék nagy része megőrzi az eredeti méretét, tehát teljes szemcsetörés nem következett be az örlés során. A 3. ábrán a kvarc kiindulási és 60 perces őrlés utáni állapotának Zeiss mikroszkópos felvétele látható. A szemcsék lekerekítettek, kevés törési felület, éles rész észlelhető rajtuk. A felületi koptatás hatására kialakult kerekded szemcsealak a jellemző. A 60 perces őrlés után a szemcséken lényeges változásként csak az tapasztalható, hogy még lekerekedettebb formát nyertek a kezdetihez képest. A mészkőőrlemény mikroszkópi felvételén látszik, hogy az örlemény szemcséi inkább szögletesebbnek mutatkoznak, mint a kvarcőrlemény szemcséi. A 4. ábrán a mészkő kiindulási és 60 perces örleményének mikroszkópos felvételei láthatóak. A szemcsék alapvetően szabálytalan alakúak, sok törési felülettel. A 60 perces őrlés követően a nagyobb méretü szemcsék felülete simább lett, az alakjuk lekerekítetté, gömbszerübbé vált. A kvarc szemcsék nehezebb őrölhetőségét vizsgálva $M u c s i$ [2] munkássága alapján, arra következtetünk, hogy a szferikus alakkal rendelkező kvarc, hasonlóan az általa vizsgált klinkerhez kisebb őrlési ellenállást fejt ki, mint a kubikusabb szemcsealakkal rendelkező mészkő, ezért nem szenved megfelelő mértékben törést a szemcse. Valószínúleg a kvarc szemcsék behúzása az őrlőtest által csak részben történik meg. Az anyagok örlés során eltérő viselkedésének bemutatá- 


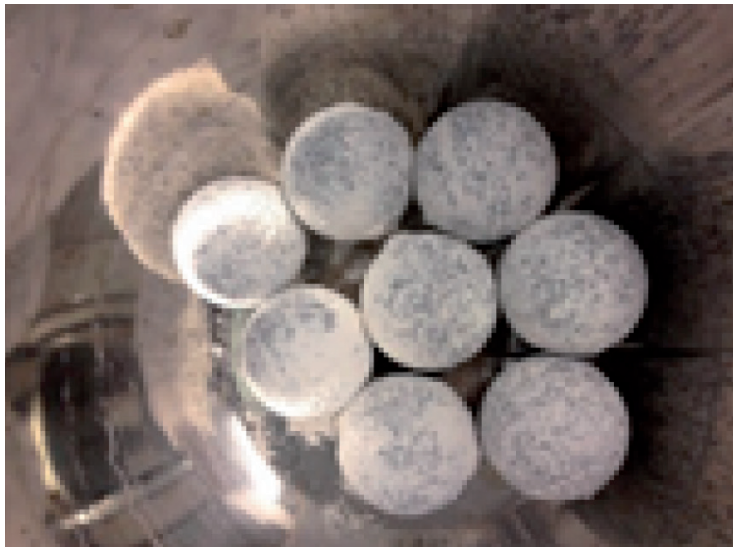

5. ábra Mészkő őrlése - jelentős feltapadás

Fig. 5 Limestone grinding - significant adhesion

sára a betapadást is vizsgáltuk (5. ábra), mely alapján megállapítható hogy a kvarc esetén nem tapasztalható feltapadás az örlőtestekre és a malom falazatára, míg, a mészkőnél viszont ez több grammnyi mennyiségü anyagréteg is felrakódott, elsősorban az őrlőtestek felületére. Az őrlőtestek felületén keletkező bevonat rontja az őrlési hatékonyságot, mely magyarázza a medián szemcseméret és a fajlagos őrlési munka közötti nem linearitást a 106-250 $\mu \mathrm{m}$-es frakció őrlése során. A tiszta mészkő őrlésénél keletkező finom töretrész az őrlési idő hosszabbodásával az őrlőtesten bevonatot képez (5. és 6. ábra).

\subsection{Kvarc és mészkő egyuittőrlési eredményei}

Együttőrlés során a 25,50 , és 75 térfogatszázalékos keverékek szemcseméret változásait vizsgáltuk. A mészkőtartalom növekedésével a feladási anyagban egyre finomabb őrleményt kapunk adott fajlagos őrlési munka befektetése mellett. A 7. ábrán látható, hogy a magasabb mészkőtartalmú keverékek (50 és 75\%) medián szemcsemérete alacsonyabb adott fajlagos őrlési munka mellett, mint a 100\%-os mészkő őrlése esetén. Az utol-

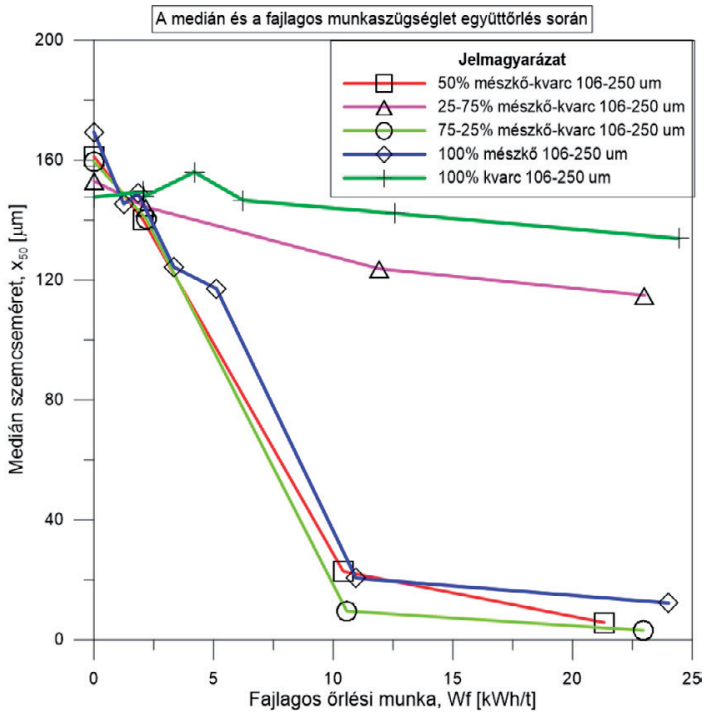

7. ábra A medián változása a fajlagos örlési munkaszükséglet függvényében mészkökvarc együttörlése során

Fig. 7 The median particle size as a function of the specific grinding work in case if limestone-quartz intergrinding

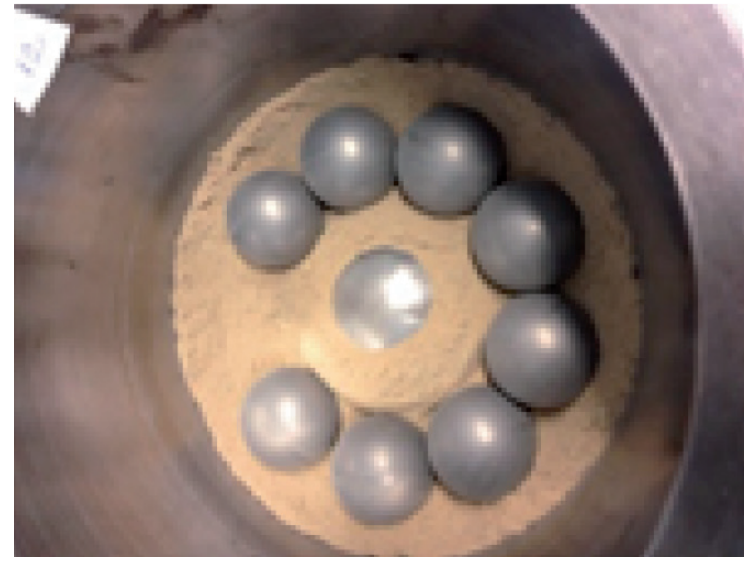

6. ábra Kvarc örlése - nincs feltapadás

Fig. 6 Quartz grinding - no adhesion

só mérési pontban (60 perces őrlés) a medián szemcsemérete az 50 és 75\%-os mészkőtartalmú keveréknek kisebb 5,75 $\mu \mathrm{m}$ és 3,12 $\mu \mathrm{m}$, mint a tiszta mészkőé, 12,23 $\mu \mathrm{m}$. A 25\% mészkövet tartalmazó őrlési görbe a tiszta kvarcéval közel megegyező, de a kis mészkőtartalomnak köszönhetően simább lefutású, kismértékü szemcseméret csökkenéssel (114,9 $\mu \mathrm{m})$ (7. ábra).

A 8. ábrán a 60 perces őrlést követően vizsgáltuk az anyagok szemcseméretsürüség függvényét 106-250 $\mu$ m-es frakció esetén. Az értékek bimodális görbéket írnak le. A 100\%os mészkő tartalomnál a módusz a durvább szemcseméret nagyság felé tolódik el. A 75\%-os mészkőtartalom esetén a gyakoriság értéke felcserélődik az 50 és a 100\%-os görbékhez képest, itt a módusz értéke a finomabb szemcseméret frakcióban van. A csúcsértékeknél a szemcseméret alakulása: 50\% mészkőtartalom esetén 152,45 $\mu \mathrm{m}$; 75\% mészkőtartalom esetén $2,27 \mu \mathrm{m} ; 100 \%$ mészkőtartalom esetén 152,45 $\mu \mathrm{m}$. A 9. ábrán a 106-250 $\mu$ m-es frakciójú kvarc-mészkő együttőrlés medián szemcseméretei kerültek feltüntetésre a kvarc tartalom függvényében 10 és $20 \mathrm{kWh} / \mathrm{t}$ fajlagos munkaszükséglet mellett. A feladott anyag kvarc tartalmának növelésével a medián

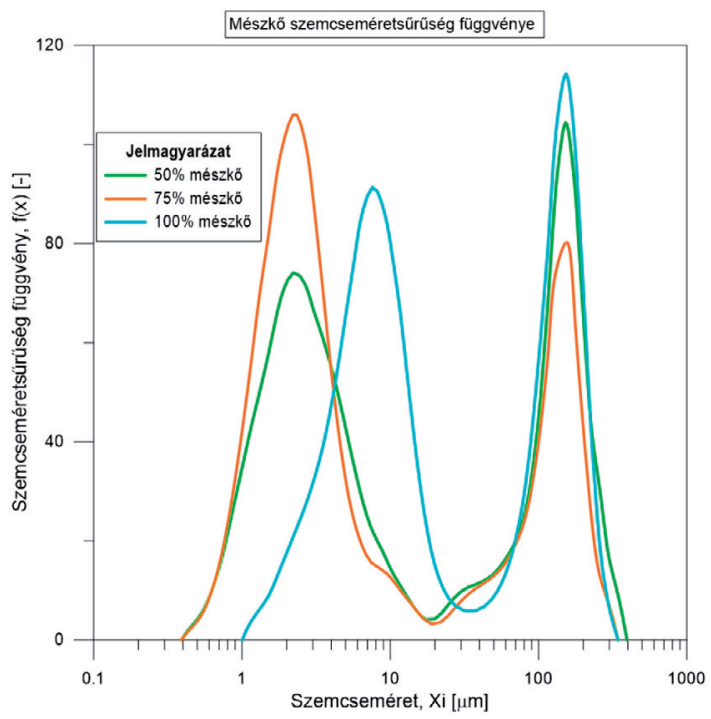

8. ábra 106-250 بm-es frakció szemcseméret-sürüségfüggvénye 60 perces mészkökvarc együttőrlésnél

Fig. 8 Particle size density function of 106-250 $\mu \mathrm{m}$ fraction at 60 min limestonequartz intergrinding 


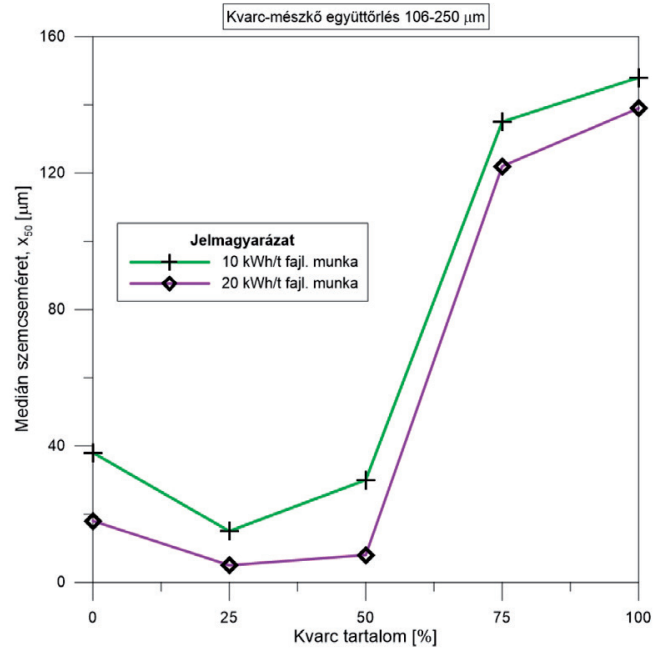

9. ábra Medián szemcseméret változása a kvarc tartalom függvényében Fig. 9 Median particle size as a function of the quartz content

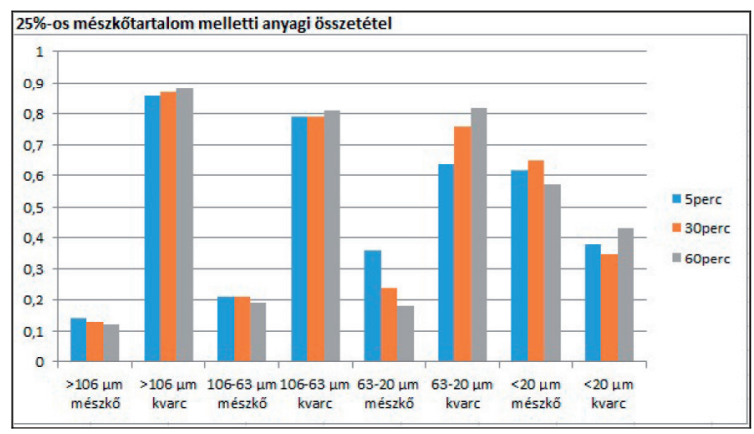

$a$
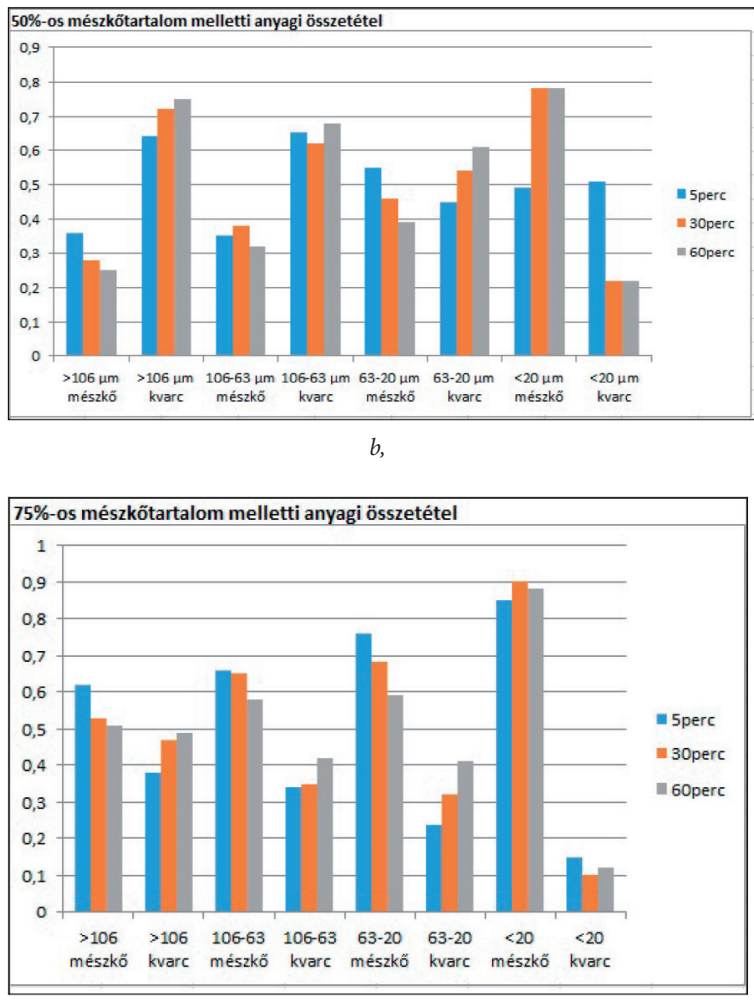

10. ábra Az örlemény anyagi összetétele kvarc-mészkő együttőrlés esetén

Fig. 10 Material composition of the ground material in case of quartz-limestone intergriding szemcseméret a durvább szemcsenagyságok felé tolódik el. Az együttőrlés $25 \%$-os kvarc tartalom mellett a legideálisabb, ekkor a legkisebbek az 50\%-os szemcsemérethez tartozó értékek. 10 és $20 \mathrm{kWh} / \mathrm{t}$ fajlagos őrlési munka befektetésnél is az 50\%-os kvarc adagolás alacsonyabb medián szemcseméretet eredményezett az őrleményben, mint a tiszta mészkő esetén. Ezt azzal magyarázhatjuk, hogy a kvarc jelenléte az örleményben csökkentette a finom szemcsék összetapadásának mértékét, illetve a kvarc szemcsék kvázi őrlőtestként részt vettek az őrlési folyamatban. A kvarc-mészkő együttőrlési kísérleteket követően a különböző őrlési időknél kapott őrleményeket szemcseméret frakciókra bontottuk, majd anyagi összetételt határoztunk meg az egyes frakciókon, hogy lássuk a mészkő és kvarc frakciónkénti eloszlását. Az összetétel eredményeket a 10. ábra mutatja. A vizsgálatból megállapítható, hogy a mészkő a $<20 \mu$ m-es tartományban feldúsul, míg a kvarc inkább a durva szemcseméret tartományban dúsul fel (10. ábra). A 25\%-os mészkőtartalom esetén a legdurvább $>106 \mu \mathrm{m}$-es frakcióban a mészkő tömeghányada jelentősen lecsökken, 14\%-ra már 5 perces őrlést követően, majd tovább csökken az őrlési idővel, ebben a frakcióban párhuzamosan ezzel a kvarc tömeghányada 86\%ra nő, majd folyamatosan nő az őrlési idővel. A 63-106 $\mu$ m-es frakcióban ugyanez a tendencia figyelhető meg, habár ebben a frakcióban a mészkőtartalom közelebb áll a kiindulási 25\%hoz, értéke 20\% körül változik az örlési idővel. A 20-63 $\mu \mathrm{m}$-es frakcióban a kiindulási állapothoz képest 5 perces őrlési időnél több a mészkő $35 \%$, majd folyamatosan csökken az őrlési idővel 18\%-ra. A <20 $\mu \mathrm{m}$-es részben a mészkőtartalom jelentősen eltér az eredeti $25 \%$-os értékröl. 5 perces örlésnél $49 \%$ a mészkőtartalom, majd az őrlési idővel tovább nő egészen 78\%-ig. Az 50\%-os mészkőtartalom esetén a $>106 \mu \mathrm{m}$-es tartományban a mészkő tömeghányada hasonlóan alakul a 25\%-os örléséhez, értéke 25\%-ra csökken 60 perc őrlést követően. A kvarc tömeghányada itt is nő 75\%-ra. A 63-106 $\mu \mathrm{m}$-es frakcióban a mészkö- és kvarctartalom lényegében nem változik, a 20-63 $\mu \mathrm{m}$-es tartományban pedig a kiindulási értékhez áll közel, 50\% a mészkőtartalom. A $<20 \mu \mathrm{m}$-es frakcióban a mészkő a 30 perces őrlés után feldúsul. Értéke nagymértékben eltér a kiindulásitól, közel 80\% lesz. A 75\%-os mészkőtartalomnál a > 106 $\mu \mathrm{m}$-es tartományban a mészkő tömeghányada $62 \%$-ról 51\%-ra csökken az örléseket követően, míg a kvarc értékei 49\%-ra nőnek. A 63-106 $\mu \mathrm{m}$-es frakcióban a mérés eredményeiben nagy ingadozás nem jelentkezik, a mészkőtartalom $60 \%$ körül alakul. A 20-63 $\mu \mathrm{m}$-es szemcseméret tartomány esetében a 75\%os mészkőtartalom jelentősen lecsökken, 60 perc elteltével csak 59\% lesz, a kvarc értéke 41\%-ra nő a kiindulási 25\%-ról. A legkisebb szemcseméret frakcióban itt is a mészkő feldúsulása figyelhető meg. Legnagyobb értékét a 30 perces őrlés után veszi fel, itt a dúsulás mértéke 90\%, majd kis mértékben csökken.

\subsection{Különböző szemcseméretü együttőrlések eredményei}

A további vizsgálatok során mindkét anyagnál a saját, de eltérő szemcseméretü (106-250 $\mu \mathrm{m}$ és 32-106 $\mu \mathrm{m}$ ) minták keveréke került feladásra. A kvarc eltérő szemcseméret frakciójának őrléséből származó medián értékeket a fajlagos őrlési munka függvényében a 11. ábrán láthatjuk. Az őrlemény medián szemcsemérete lineáris csökkenést mutat a befektetett munka függvényében. Az eltérő frakciók együttőrlésénél a medián 


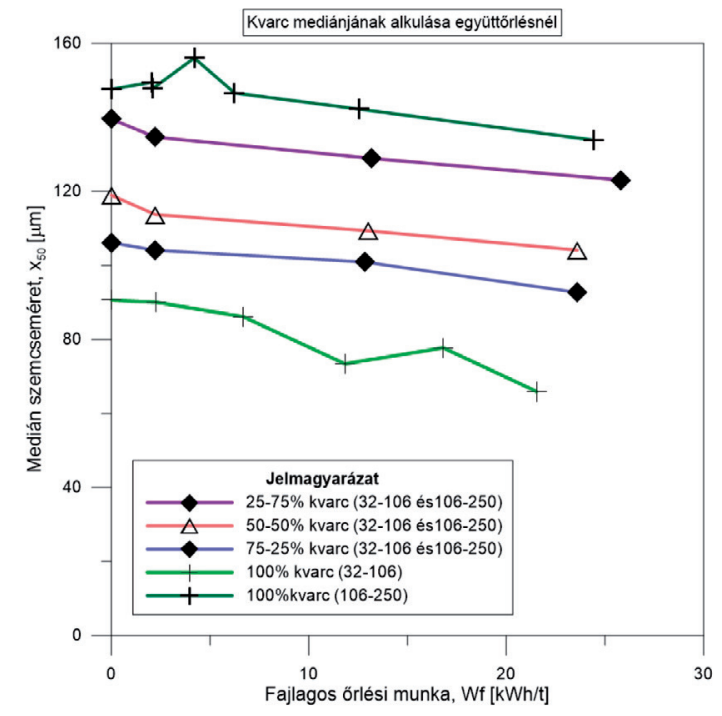

11. ábra Az őrlemény mediánjának alakulása különbözö szemcseméretü kvarc frakciók együttőrlésnél

Fig. 11 Median particle size at the intergrinding of quatz with different size fractions

szemcseméret közel azonos mértékben csökken a fajlagos őrlési munka befektetésének függvényében. Megállapítható, hogy minél inkább a 32-106 $\mu$ m-es frakciójú anyag mennyisége növekszik a keverékben, annál jobban közelítik a görbék ennek a frakciónak a tiszta örlési eredményeit. A mészkő különböző frakcióinak együttőrlése eredményét a 12 ábrán mutatjuk be. A medián vizsgálata során látható, hogy minden anyagi összetételnél jelentősen csökken a medián szemcseméret a fajlagos örlési munka függvényében (12. ábra). Mindhárom keverék esetében a $25 \mathrm{kWh} / \mathrm{t}$ fajlagos örlési munka befektetés hatására $20 \mu \mathrm{m}$ közeli őrlemény medián értéket kapunk. A 13. ábrán az eltérő szemcsefrakciók együttőrlésének medián szemcseméret értékei láthatók 10 és $20 \mathrm{kWh} / \mathrm{t}$ befektetett fajlagos munka mellett a kisebb, 32-106 $\mu$ m-es frakció függvényében vizsgálva. Kvarc együttőrlése során, minél több a feladás finomrész tartalma, annál kisebb lesz a medián szemcseméret is. Mészkőnél azt tapasztaltuk, hogy 0 és 100\% finomrész tartalomnál is ugyan az a medián szemcseméret a vizsgált fajlagos munkáknál.

\section{4. Összefoglalás}

A kutatómunka során különböző őrölhetőségű anyagok együttőrlési vizsgálatát végeztük el univerzális Hardgrove malomban. A kétkomponensű együttőrléshez kvarcot és mészkövet alkalmaztunk, a kvarc nehezen örölhető, de tapadásra nem hajlamos, míg a mészkő könnyen őrölhető és aggregációra, tapadásra hajlamos anyag. A különőrlési mérési eredményeink bemutatták a mészkő és a kvarc eltérő viselkedését az őrlés során. A mészkő az őrlési folyamat kezdetén könnyen aprózódott, majd az őrlés elörehaladtával jelentős betapadás volt megfigyelhető az őrlőtérben, miközben az őrlés hatékonysága jelentősen csökkent. Ezzel szemben a kvarc csak kis mértékben aprózódott az őrlőtérben, jellemzően csak felületi koptatás történt a teljes szemcsetörés helyett, mely visszavezethetö a kvarc szemcsék gömbszerű szemalakjára. Az együttőrlési mérési eredményeink alapján megállapítható, hogy a mészkőtartalom növelésével a feladásban egyre finomabb őrleményt

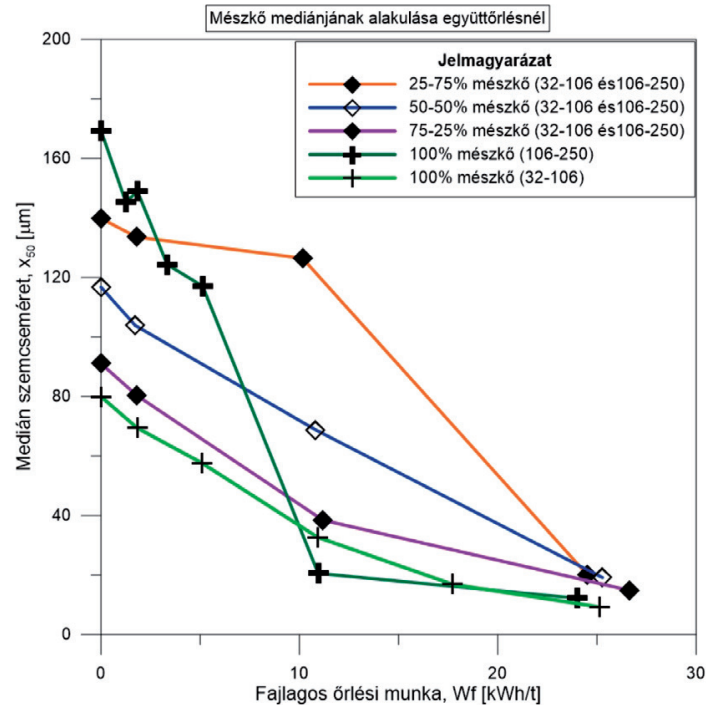

12. ábra Medián változása különböző méretü mészkő frakciók együttőrlésekor

Fig. 12 Median particle size at the intergrinding of limestone with different size fractions

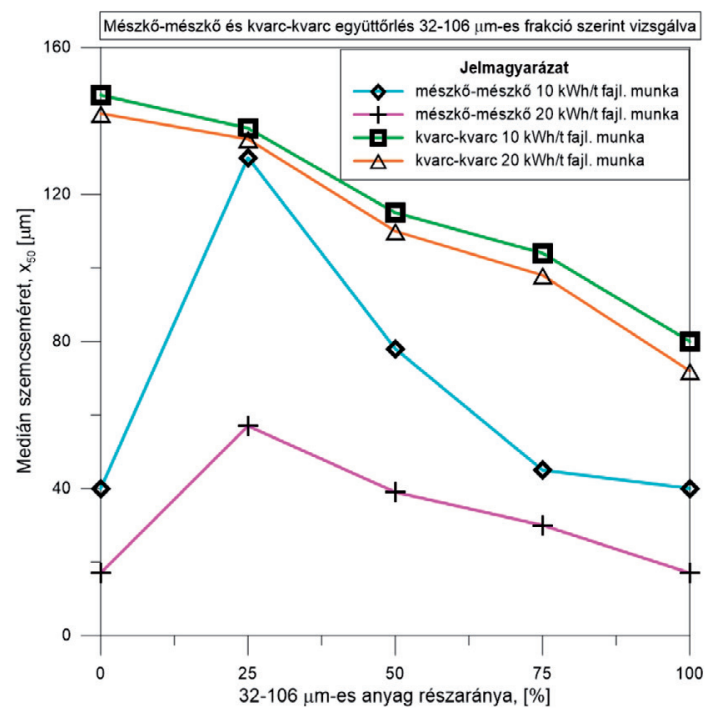

13. ábra Medián szemcseméret változása a 32-106 $\mu$ m-es frakció részaránya szerint kvarc és mészkő különböző méretü frakcióinak együttőrlésekor

Fig. 13 Median particle size as a function of the mass percent of 32-106 $\mu \mathrm{m}$ fraction at the intergrinding of quatz and limestone with different size fractions

kaptunk adott fajlagos őrlési energia befektetés esetén. Az őrlemények anyagi összetételének frakciónkénti meghatározásából megállapítható, hogy a finomabb mészkő feldúsul a kvarccal történő együttőrlés során a finom, $<20 \mu \mathrm{m}$-es tartományban. Méréseink alapján megállapítható, hogy a keményebb anyag az együttőrlés során elősegíti az őrlést, egyrészről az adhéziós erők lekötésével, más részről az őrlési folyamatban kvázi őrlőtestként való részvételként.

\section{Köszönetnyilvánítás}

A kutató munka a „Fenntartható Nyersanyag-gazdálkodási Tematikus Hálózat - RING 2017” című, EFOP-3.6.2-16-201700010 jelü projekt részeként a Szechenyi2020 program keretében az Európai Unió támogatásával, az Európai Szociális Alap társfinanszírozásával valósult meg. 
Hivatkozások

[1] Csőke B. (2005): Előkészítéstechnika: Aprítás és osztályozás, Miskolci Egyetem, Eljárástechnika Tanszék

[2] Mucsi G. (2009): Vizsgálati eljárások fejlesztése finom szemcseméretű anyagok őrölhetőségének, valamint különleges körülmények mellett történő őrlés energiaszükségletének meghatározása, Doktori értekezés, Miskolci Egyetem

[3] Csőke B. - Rácz Á. - Mucsi G. (2013): Determination of the Bond work index of binary mixtures by different methods, International Journal of Mineral Processing, 123 78-86,

https://doi.org/10.1016/j.minpro.2013.05.004

[4] Ipek, H. - Ucbas, Y. - Hosten, C. (2005 a): The bond work index of mixtures of ceramic raw materials. Miner. Eng. 18, 981983 (1), https://doi.org/10.1016/j.mineng.2004.12.014

[5] Öner, M., (2000): A study of intergrinding and separate grinding of blast furnace slag cement. Cem. Concr. Res. 30, 473-480, https://doi.org/10.1016/S0008-8846(00)00197-6

[6] Abouzeid, A.-Z. M. - Fuerstenau, D. W. (2009): Grinding of mineral mixtures in high-pressure grinding rolls. Int. J. Miner. Process. 93, 59, 65, https://doi.org/10.1016/j.minpro.2009.05.008Get rights a
[7] Tavares, L. M. (2005): Particle weakening in high-pressure roll grinding. Miner. Eng. 18 (7), 651-657, https://doi.org/10.1016/j.mineng.2004.10.012

[8] Ellerbrock, H. G. - Sprung, S. - Kuhlmann, K. (1990): Particle size distribution and properties of cement, Part III: in fl uence of the grinding process. Zement-Kalk-Gips 3/1990, Edition B. 13 19,

[9] Faitli József - Czél Péter (2014): Matrix modell simulation of a Vertical Roller Mill with High-Efficiency Slat Classifier, Chem. Eng. Technol. 37, No. 5, 1-9, https://doi.org/10.1002/ceat.201300665

[10] Mag G. A. (2015)Térfogati alapú körfolyamatos örölhetőségi vizsgálati módszerellenőrzése, Miskolci Egyetem, Szakdolgozat

[11] Mucsi G. (2008) Fast test method for the determination of the grindability of fine materials, Chemical Engineering Research and Design, 86:(4) pp. 395-400, https://doi.org/10.1016/j.cherd.2007.10.015

$\underline{\text { Ref.: }}$

Gregus, Éva - Rácz, Ádám - Csőke, Barnabás: Intergrinding of materials with different grindability in Universal Hardgrove mill Építőanyag - Journal of Silicate Based and Composite Materials, Vol. 70, No. 3 (2018), 90-96. p. https://doi.org/10.14382/epitoanyag-jsbcm.2018.17

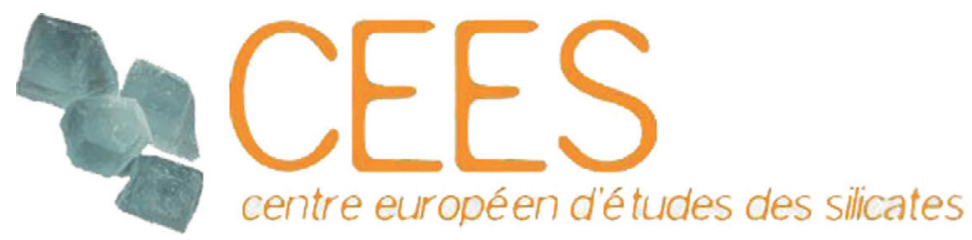

\section{About CEES}

CEES is the organisation representing the European Silicate Industry. It brings together Western European Producers of Soluble Silicates. CEES is a Sector Group of Cefic.

CEES members manufacture more than 700,000 tonnes (1998 figures) of soluble silicates (calculated as $\mathrm{SiO}_{2}$ ) representing more than $90 \%$ of total West European production. More than half this production is used as a feedstock raw material for further chemical manufacture, mostly silicas and aluminosilicates. Overall, the silicate industry makes a valuable contribution to the Western European economy.

CEES members operate modern, fuel-efficient plants maintaining the highest standards of health and safety to protect both the workforce and the environment. All CEES members full support and implement the Europewide Cefic Responsible Care initiative.

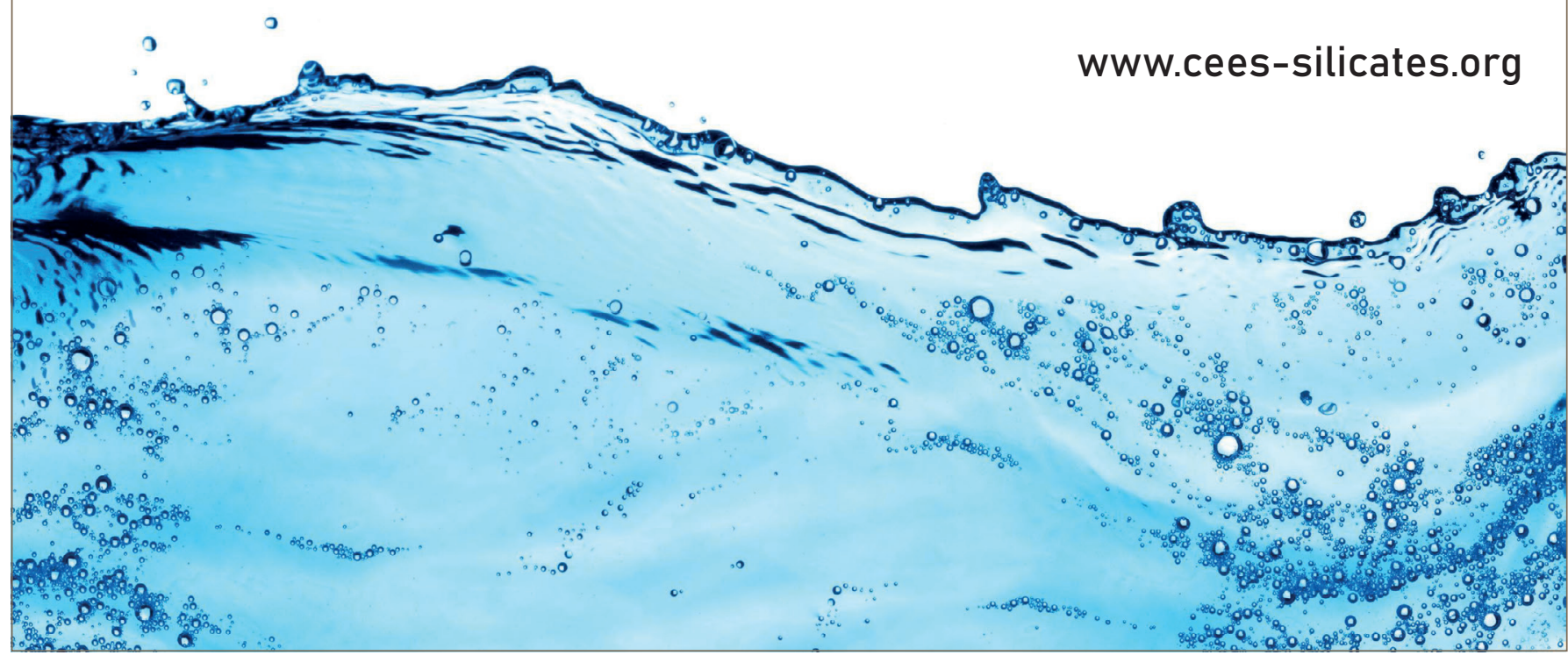

